\section{Category}

Organo- and

Biocatalysis

\section{Key words}

iminium ions

supramolecular chemistry

thioureas

\title{
Thiourea-Assisted Iminium Catalysis
}

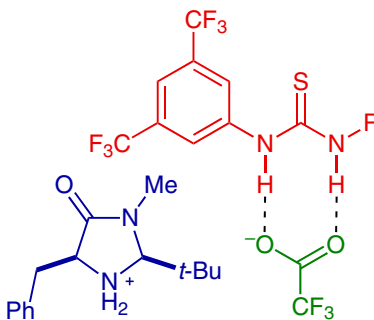

1a $\mathrm{R}=3,5-\left(\mathrm{F}_{3} \mathrm{C}\right)_{2} \mathrm{C}_{6} \mathrm{H}_{3}$ 1b $R=P h$<smiles>COC(=O)C(F)(F)C(=O)OC1NC(Cc2ccccc2)C(=O)N1C</smiles>

2
An intramolecular Diels-Alder reaction:<smiles>O=C/C=C/CCC/C=C/C=C/c1ccccc1</smiles><smiles>O=C(F)/C=C/c1ccccc1</smiles><smiles>[N+]n1ccc2ccccc21</smiles>

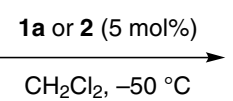

$\underset{\mathrm{PhMe},-10^{\circ} \mathrm{C}}{\stackrel{1 a}{\mathrm{O}} \mathbf{2}(10 \mathrm{~mol} \%)}$

with 2

with 1a

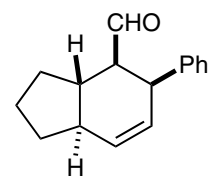

$1 \mathrm{~h}, 28 \%$ conv er $=98: 2$, endo/exo $>20: 1$

$1 \mathrm{~h}, 75 \%$ conv er $=97: 3$, endo/exo $>20: 1$<smiles>Cn1cc(C(CC=O)c2ccccc2)c2ccccc21</smiles>

$45 \mathrm{~h}, 27 \%$ conv. $19 \%$ yield, er $=90.5: 9.5$

$45 \mathrm{~h}, 92 \%$ conv. $81 \%$ yield, er $=89.5: 10.5$
Significance: A thiourea-assisted iminium catalysis has been described. It was found that simple thioureas accelerate previously established reactions of $\alpha, \beta$-unsaturated aldehydes with MacMillan's organocatalyst, presumably by binding to the counteranion of the iminium intermediate. The use of chiral thioureas did not have a significant effect on the enantioselectivity.
SYNFACTS Contributors: Benjamin List, Ji Hye Kim Synfacts 2013, 9(1), 0102 Published online: 17.12.2012 Dol: 10.1055/s-0032-1317904; Reg-No.: B11712SF
Comment: The profound influence of anions on reactivity and selectivity in asymmetric iminium catalysis is well established (S. Mayer, B. List Angew. Chem. Int. Ed. 2006, 45, 4193). Therefore, thioureas could be expected to influence the activity and selectivity by anion binding during the catalysis (see Review below). In the current report, a mild positive influence of thioureas on reactivity is demonstrated. Development of a chiral thiourea as the only source of asymmetric information remains as the true challenge of this approach.

Review: Z. Zhang, P. R. Schreiner Chem. Soc. Rev. 2009, 38, 1187-1198. 